\title{
A statistical approach to the study of concrete carbonation
}

\author{
I. Garcia-Lodeiro $₫$ $\bowtie$ J.G. Palomo ${ }^{\text {, A. Aalomo }}$, A. Fernández-Jiménez ${ }^{\mathrm{a}}$ \\ a. Instituto de Ciencias de la Construcción Eduardo Torroja (IETcc-CSIC) (Madrid, Spain) \\ b. Universidad Politécnica de Madrid (Madrid, Spain) \\ $\triangle$ iglodeiro@ietcc.csic.es
}

\author{
Received 14 January 2013 \\ Accepted 12 September 2013 \\ Available on line 12 March 2014
}

\begin{abstract}
Carbonation is one of the factors that conditions reinforced concrete durability, while porosity is one of the parameters that determines the carbonation rate: as a rule, the greater the porosity, the higher the rate. While many papers have been published on the effect of $\mathrm{CO}_{2}$ penetration in the pore solutions of concretes prepared under different experimental conditions, the literature has yet to address the joint effect of the factors considered in concrete design, such as the water/cement $(w / c)$ ratio, type of cement, type of aggregate and presence of admixtures. The present paper discusses the findings of a statistical study of the impact of the aforementioned factors on both system porosity and carbonation rate. The type of cement, individually and in its interaction with the rest of the factors, proved to be the major determinant in concrete carbonation.
\end{abstract}

KEYWORDS: Carbonation; Porosity accessible to water; Concrete; Factorial design

Citation/Citar como: García-Lodeiro, I.; Palomo, J.G.; Palomo, A.; Fernández-Jiménez, A. (2014) A statistical approach to the study of concrete carbonation Mater. Construcc. 64 [313], e001 http://dx.doi.org/10.3989/mc.2014.00413

RESUMEN: Una aproximación estadística al estudio de la carbonatación del hormigón.- La carbonatación es uno de los factores que supedita la durabilidad del hormigón armado, siendo la porosidad uno de los parámetros que más condicionan la velocidad de carbonatación. Son muchos los trabajos que estudian el efecto de la penetración del $\mathrm{CO}_{2}$ en la solución de los poros de hormigones preparados bajo distintas condiciones experimentales, sin embargo, no se encuentran referencias que analicen de forma conjunta el efecto de ciertos factores como son la relación agua/cemento (a/c ratio), el tipo de cemento, el tipo de árido y la presencia de aditivos, normalmente consideradas a la hora de diseñar un hormigón. En este trabajo se discuten los resultados obtenidos tras realizar un estudio estadístico del efecto que tienen los factores previamente mencionados, tanto en la porosidad de estos sistemas como en su nivel de carbonatación. El cemento tanto de manera individual como en sus interacciones con el resto de los factores es el factor que mas afecta a la carbonatación del hormigón.

PALABRAS CLAVE: Carbonatación; Porosidad accesible al agua; Hormigón; Diseños factoriales

Copyright: (C) 2014 CSIC. This is an open-access article distributed under the terms of the Creative Commons Attribution-Non Commercial (by-nc) Spain 3.0 License.

\section{INTRODUCTION}

Portland cement concrete is the hydraulic binder most universally used in construction. Its high strength and durability, combined with its low price, have made it one of the most competitive products on the market. It is not an isolated system, however, but interacts with environmental moisture, temperature and $\mathrm{CO}_{2} \ldots$, all of which induce structural and compositional changes in the material. Carbonation is among the processes that affects concrete most intensely (1-4).

Concrete carbonation begins with the penetration of atmospheric $\mathrm{CO}_{2}(\mathrm{~g})$ across its surface and its subsequent diffusion inside the material, where it dissolves in the aqueous phase $\left(\mathrm{CO}_{2}(\mathrm{aq})\right)$. The result of 
solubilisation is the formation of ionic species $\left(\mathrm{HCO}_{3}^{-}\right.$ and especially $\mathrm{CO}_{3}^{2-}$ ) that interact with the various calcium-bearing phases of the cement, primarily portlandite, leading to the precipitation of calcium carbonate, normally in the form of calcite. Carbonation is not in itself harmful and in some cases may even be beneficial, for it reduces porosity and forms a protective layer on the concrete surface. Nonetheless, the associated decline in $\mathrm{pH}$ values (due to the consumption of the $\mathrm{OH}^{-}$ions in the medium) may favour the destruction of the passive layer that protects the steel reinforcement in the concrete, inducing corrosion.

Reinforced concrete carbonates from the surface inward, advancing across the pores until the carbonation front reaches the steel. In all the many models described in the literature for predicting carbonation depth, $\mathrm{CO}_{2}(\mathrm{~g})$ ingress depends on the porosity of the material and its water content (6-8). A priori, higher concrete porosity may be thought to induce speedier carbonation front progress and greater loss of alkalinity (porous concretes carbonate very rapidly) (9-11).

The literature contains many references to the effect of carbonation on concretes with different designs and characteristics (9-18). Nonetheless, no analyses have been published on the joint and simultaneous effect of factors regarded as essential to concrete design, such as the water cement (w/c) ratio, cement type, aggregate type and presence of admixtures.

The purpose of the present study was to apply statistical tools to ascertain the effect of the aforementioned factors on concrete carbonation measured as variations in porosity.

\section{EXPERIMENTAL}

\subsection{Experimental design: response variables and factors considered}

Two factorial designs were developed (19-21) to analyse the effect on two response variables:

- porosity accessible to water (PAW)

- carbonation rate

of four factors: $A=$ presence of a superplasticiser; $\mathrm{B}=$ water/cement ratio; $\mathrm{C}=$ aggregate type; and $\mathrm{D}=$ cement type. With two levels for each factor, listed in Table 1 , a total of $2^{4}=16$ types of concrete were prepared, as summarised in Table 2 . The design factor are listed under columns A, B, C and D, while each row gives the combination of factors defining each concrete (listed under the left-most column).

The specimens were prepared in a precast concrete plant in 16 consecutive weeks in random order pursuant to the experimental design (order as shown in Table 2) and subsequently shipped to the laboratory for testing.

A total of $400 \mathrm{~kg}$ of cement was used per cubic metre of concrete. The grey and white cements
TABLE 1. Factors studied to analyse concrete carbonation

\begin{tabular}{lll}
\hline Factor & \multicolumn{1}{c}{ Factor definition } & \multicolumn{1}{c}{ Factor level } \\
\hline A & $\begin{array}{l}\text { Presence of } \\
\text { superplasticiser }\end{array}$ & No $\left(\mathrm{X}_{\mathrm{a}}=-1\right)$ Yes $\left(\mathrm{X}_{\mathrm{b}}=+1\right)$ \\
B & Water/cement ratio & $0.32\left(\mathrm{X}_{\mathrm{a}}=-1\right) 0.42\left(\mathrm{X}_{\mathrm{b}}=+1\right)$ \\
C & Type of aggregate & $\begin{array}{l}\text { Siliceous }\left(\mathrm{X}_{\mathrm{a}}=-1\right) \text { Limestone } \\
\left(\mathrm{X}_{\mathrm{b}}=+1\right)\end{array}$ \\
D & Type of cement & White $\left(\mathrm{X}_{\mathrm{a}}=-1\right)$ Grey $\left(\mathrm{X}_{\mathrm{b}}=+1\right)$ \\
\hline
\end{tabular}

chosen to prepare the concretes were CI-52.5R and BL II-42.5R, respectively. The commercial superplasticiser ("Melcretet") used was added at a rate of $1.5 \%$ of cement weight. A total of $1100 \mathrm{~kg} / \mathrm{m}^{3}$ of $0 / 5$ river sand and $750 \mathrm{~kg} / \mathrm{m}^{2}$ of $6 / 13$ crushed granite was added to the siliceous aggregate concretes. The concretes with limestone aggregate contained $1100 \mathrm{~kg}$ of $4 / 12$ crushed limestone and $750 \mathrm{~kg}$ of $0 / 4$ crushed sand per cubic metre of concrete. All the specimens were cured in a climatic chamber for 28 days prior to shipping and testing.

All but one of the surfaces of the specimens studied $\left(15 \times 15 \times 7.5-\mathrm{cm}^{3}\right.$ parallelepipeds: see Figure 1) were covered with plastic paint to prevent air from penetrating into the pores on those sides. The casting surface, which was left unpainted to favour $\mathrm{CO}_{2}$ ingress, measured $15 \times 15 \mathrm{~cm}^{2}$. Twelve specimens were prepared per batch (type of concrete). Two were tested upon receipt as 28-day control samples. The other 10 were exposed to accelerated carbonation as described in item 2.3.

TABLE 2. Concretes studied by the factors listed in Table 1 (shown by random order of preparation)

\begin{tabular}{|c|c|c|c|c|}
\hline $\begin{array}{l}\text { Concrete } \\
\text { ID }\end{array}$ & $\begin{array}{c}\mathrm{A} \\
\text { (admixture) }\end{array}$ & $\begin{array}{c}\text { B } \\
\text { (/a/c ratio) }\end{array}$ & $\begin{array}{c}\mathrm{C} \\
\text { (aggregate) }\end{array}$ & $\begin{array}{c}\text { D } \\
\text { (cement) }\end{array}$ \\
\hline H-4 ${ }^{(* 1)}$ & No & 0.42 & Siliceous & White \\
\hline H-7 ${ }^{(* 2)}$ & No & 0.42 & Siliceous & Grey \\
\hline H-11 ${ }^{(* 3)}$ & No & 0.42 & Limestone & White \\
\hline $\mathbf{H}-3^{(* 4)}$ & No & 0.42 & Limestone & Grey \\
\hline H-6 ${ }^{(* 5)}$ & Yes & 0.42 & Siliceous & White \\
\hline H-16 ${ }^{(* 6)}$ & Yes & 0.42 & Siliceous & Grey \\
\hline $\mathbf{H}-2^{\left({ }^{*} 7\right)}$ & Yes & 0.42 & Limestone & White \\
\hline H-8 ${ }^{(* 8)}$ & Yes & 0.42 & Limestone & Grey \\
\hline H-1 ${ }^{(* 9)}$ & No & 0.32 & Siliceous & White \\
\hline H-13 ${ }^{(* 10)}$ & No & 0.32 & Siliceous & Grey \\
\hline H-15 ${ }^{(* 11)}$ & No & 0.32 & Limestone & White \\
\hline H-12 ${ }^{(* 12)}$ & No & 0.32 & Limestone & Grey \\
\hline H-14 ${ }^{(* 13)}$ & Yes & 0.32 & Siliceous & White \\
\hline H-9 ${ }^{(* 14)}$ & Yes & 0.32 & Siliceous & Grey \\
\hline H-10 ${ }^{(* 15)}$ & Yes & 0.32 & Limestone & White \\
\hline H-5 ${ }^{(* 16)}$ & Yes & 0.32 & Limestone & Grey \\
\hline
\end{tabular}

(*)Week when the concrete was prepared (batching order). 


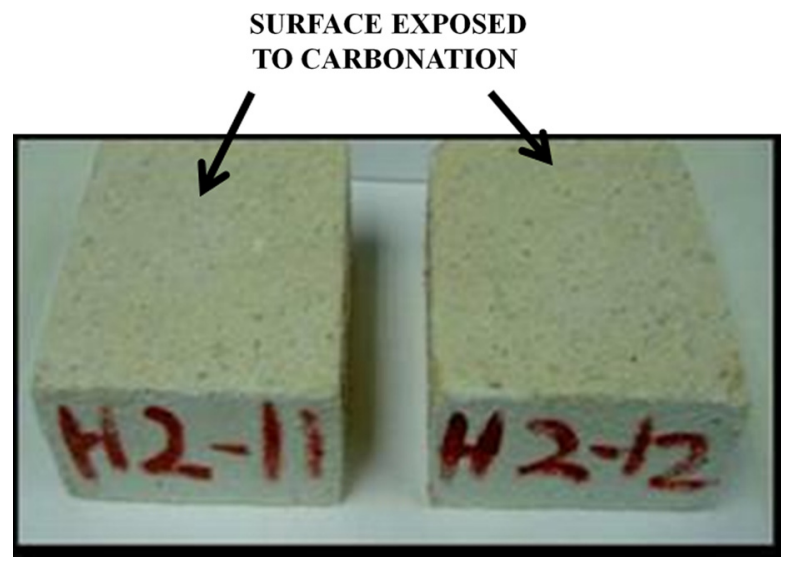

Figure 1. Concrete specimens measuring $15 \times 15 \times 7.5 \mathrm{~cm}^{3}$.

\subsection{Response variables}

The response variables analysed, as noted above, were porosity accessible to water (PAW) and carbonation rate.

Porosity accessible to water (PAW) is defined as the ratio between the volume of water-accessible pores and the total volume of the sample tested. This test was conducted as recommended by RILEM (22) using $7.5 \times 5 \times 5-\mathrm{cm}^{3}$ specimens. The specimens were first dried at $100{ }^{\circ} \mathrm{C}$ for $24 \mathrm{~h}$ to eliminate any possible water in the pores before determining the dry weight (M1). The specimens were submerged in water in a vacuum for one week and subsequently weighed first underwater (M2) and then under normal laboratory conditions (M3). The porosity accessible to water was determined as a percentage as shown in Equation [1]:

$$
\mathrm{PAW}=[(\mathrm{M} 3-\mathrm{M} 1) /(\mathrm{M} 3-\mathrm{M} 2)] \times 100[1]
$$

$$
\begin{gathered}
\mathrm{M} 1=\text { dry mass; } \mathrm{M} 2=\text { underwater saturated } \\
\text { mass (hydrostatic weight); M3=water- } \\
\text { saturated mass in air }
\end{gathered}
$$

Carbonation rate was calculated in terms of the variation in PAW after accelerated carbonation, using Equation [2]:

$$
\begin{gathered}
\text { carbonation rate }(\%)= \\
{\left[\left(\mathrm{PAW}_{\mathrm{n}}-\mathrm{PAW}_{\mathrm{i}} / \mathrm{PAW}_{\mathrm{i}}\right]^{* 100[2]}\right.}
\end{gathered}
$$

$\mathrm{PAW}_{\mathrm{n}}=$ porosity accessible to water at age " $\mathrm{n}$ " after the accelerated carbonation test $(\mathrm{n}=1,2,3,6$ or 12 months); PAW $_{\mathrm{i}}=$ initial porosity accessible to water (before the accelerated carbonation test).

\subsection{Accelerated carbonation test}

The concrete specimens were exposed to an accelerated carbonation cycle with compressed air, in which they were submerged in water and subsequently dried to stimulate $\mathrm{CO}_{2}$ penetration. The procedure, which was similar to the methods commonly described in the literature $(23,24)$, consisted of 24-hour cycles as described below.

-The specimens were submerged in the curing chamber baths for 18 hours.

-They were subsequently exposed to a stream of compressed air for 6 hours, which induced carbonation as a result of the direct contact between the specimens and the air injected into the chamber.

The specimens were exposed to accelerated carbonation for $1,2,3,6$ or 12 months, and subsequently tested.

The carbonation rate was found with phenolphthalein as described in Spanish standard UNE 112$011-94 *(25)$. This procedure detects the reduction in alkalinity prompted by carbonation from the change in colour of the material tested. Phenolphthalein turns reddish purple at $\mathrm{pH}$ values of over 9.5 (noncarbonated concrete) but is colourless at $\mathrm{pH}$ of under 8 (carbonated concrete). Figure 2 shows a number of concrete specimens selected by way of example, before and after accelerated carbonation. As the photographs show, the intense purple colour gradually faded after carbonation, providing evidence that the accelerated carbonation test is effective.

\subsection{Statistical analysis of results}

A full factorial analysis was conducted for each age studied to determine the joint effect of the four explanatory variables described above (see Table 1).
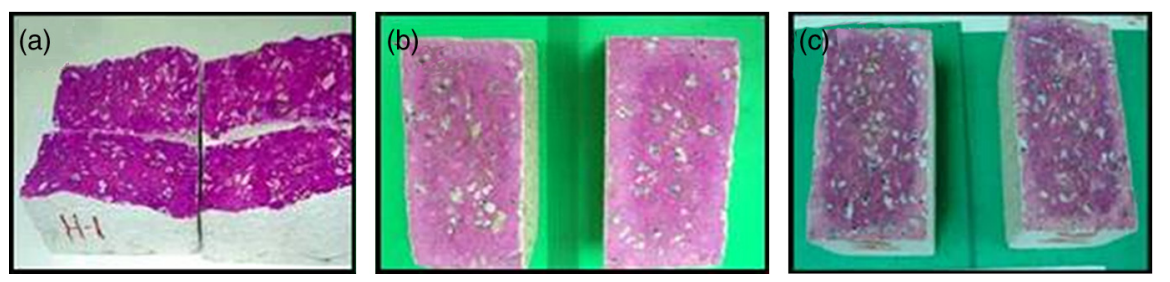

FIgURE 2. Phenolphthalein test in concrete specimens: (a) before accelerated carbonation; (b) 2-month specimen; (c) one-year specimen. 
Age was not regarded as a fifth factor in the designs, given that the existence of a correlation among the data for the various concretes at different ages ruled out the independence assumed and necessary to apply analysis of variance techniques. Two factorial designs were developed, one for each response variable, at the four ages studied.

The significance assigned to each explanatory variable and their interactions was determined with the F-test, using ANOVA methodology (19-21).

All the factorial analyses were conducted in accordance with the following criteria.

- The fourth order interaction, ABCD, was regarded as irrelevant when calculating the degrees of freedom for estimating experimental variability and drawing comparisons.

- The analyses consistently took third order interactions into consideration. When no significant interactions were detected for that order, they were eliminated from the model to

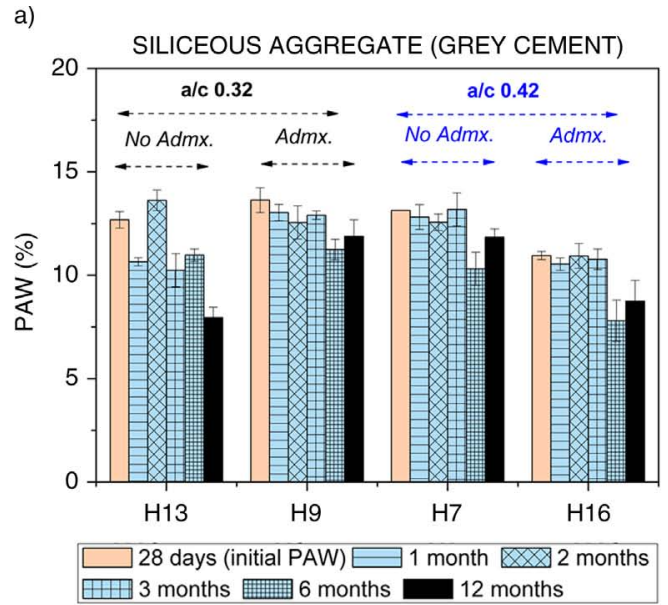

c)

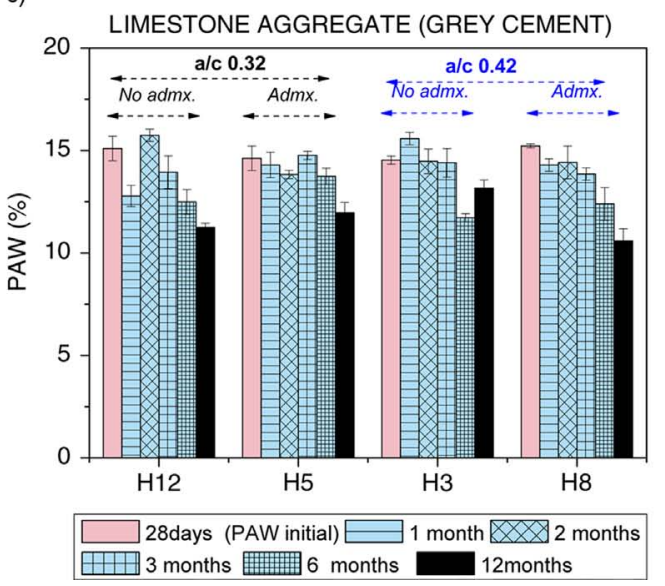

estimate experimental variability with a larger number of degrees of freedom.

- Second order interactions were likewise eliminated when no significant interactions were detected.

\section{RESULTS}

\subsection{Porosity accessible to water}

\subsubsection{Descriptive analysis}

Figure 3 shows the porosity accessible to water (PAW) findings for all the concretes listed in Table 2 at all the experimental ages. The 28-day PAW (Equation 1) was defined as the initial porosity, while the 1-, 2-, 3-, 6- and 12-month values refer to the PAW found after concrete specimen exposure to the accelerated carbonation test for those experimental periods.

The decline in the PAW (\%) in all the concretes over time, which is consistent with the effectiveness

b)

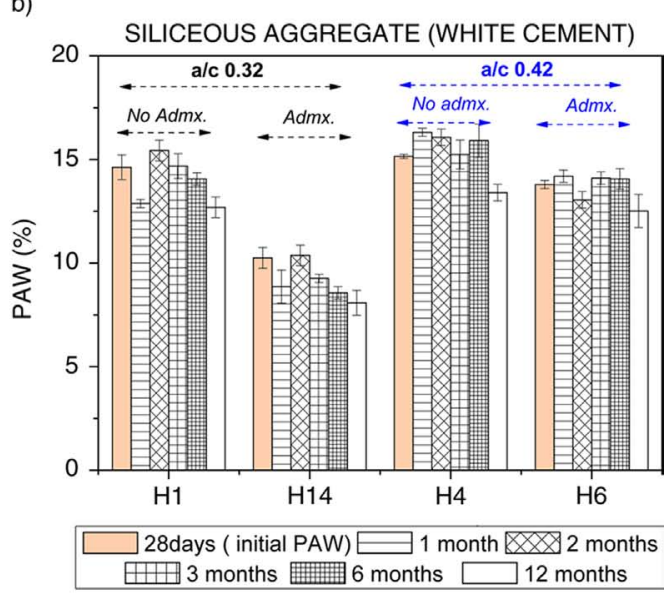

d)

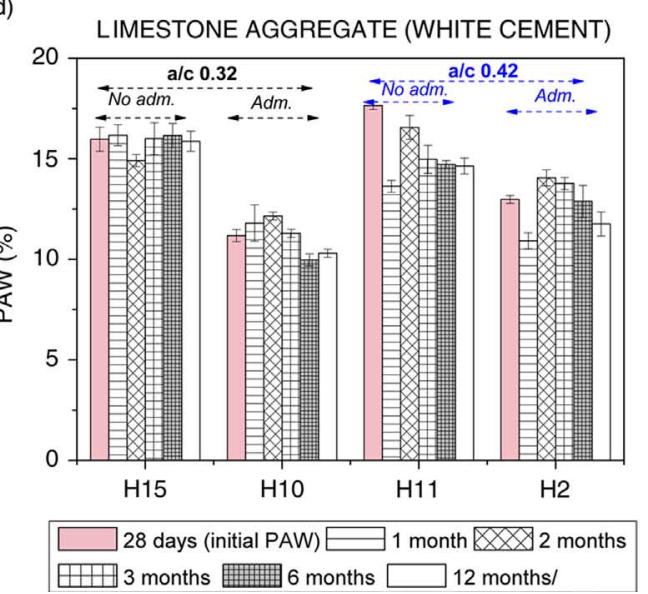

FIGURE 3. Variations in porosity accessible to water (PAW \%) in the concretes listed in Table 2. 
of the accelerated carbonation process, was interpreted as a rise in the carbonation rate with exposure time. This would be the result of the formation of a calcium carbonate whose precipitation in the concrete pores lowered overall porosity.

The graphs in Figure 3 show that the presence or absence of an admixture played an important role in initial (28-day) system porosity in concretes made with white cement, but less so in the grey cement materials, inferring the presence of significant interaction between the two factors, cement and admixture.

The explanatory variables considered and the extent of their effect on PAW and its variations were explored in detail with the statistical analyses described below.

\subsubsection{Inferential analysis of factors in $P A W$ at different ages}

The statistical significance of the factors studied and their interactions in porosity, given in Table 3, was found by applying analysis of variance to the experimental findings for all the concretes listed in Table 2.

Table 3 gives the p-values for each factor at each age. The effects found to be significant at 95\% confidence are shown in bold typeface and flagged with a superscripted " $b$ ". The table also gives the p-values for the binary and tertiary interactions (less than $0.1,90 \%$ confidence), because while they may not be significant at $95 \%$ confidence, their $\mathrm{p}$-values are low enough to be taken into consideration. The order of the significance of factors and interactions are likewise shown: note that the lower the p-value, the higher the significance.

According to these findings, the statistical significance of the four factors studied (A, B, C and D) differed. In the 28-day specimens, prior to accelerated carbonation, the factors that affected porosity accessible to water most intensely were the presence of an admixture and the type of aggregate, while interactions AD (admixture-cement) and BD (aggregate-cement) were likewise significant: in other words, the cement modified the effect of both the admixture and the aggregate.

Generally speaking, in the 2-month materials the most statistically significant factors were again the admixture (A) and type of aggregate (C), and to a lesser extent the type of cement (D). The effect of the water/cement ratio (B) was essentially negligible. Nonetheless, as in the 28-day specimens, in all the models (i.e., at all the ages studied) where significant binary interactions were observed, interaction AD (admixture-cement) was always one of them. Moreover, factor D, cement, consistently appeared in all the significant interactions. The foregoing suggests that one of the least significant factors on the individual scale (cement in this case) was of vital importance in inter-factorial interactions. This is the most noteworthy finding in the analysis of porosity.

The behaviour of the residuals did not in any case denote non-compliance with the basic model conditions with respect to the normal distribution of and homoscedasticity of the error.

These findings are consistent with the experimental data shown in Figure 3.

\subsection{Carbonation rate}

\subsubsection{Descriptive analysis}

This item discusses the analysis of the effect of the four factors on carbonation rate measured as the variation in porosity.

Figure 4 shows the carbonation rates calculated for all the concretes and ages studied (see Equation [2]), grouped by the explanatory variables defined in the experimental design. Negative carbonation values $(\%)$

TABLE 3. Ranking of factors studied by order of significance for porosity

\begin{tabular}{|c|c|c|c|}
\hline Time (months) & $\begin{array}{l}\text { Factors by order of significance for porosity } \\
\text { (p-values) }\end{array}$ & Binary and tertiary interactions & $\mathbf{S}^{2} \mathbf{R}$ \\
\hline 28 days & $\begin{array}{l}A^{b}>>C^{b}>>B>D \\
(0.0195<0.0414<0.3143<0.7324)\end{array}$ & $\begin{array}{l}\mathrm{AD}^{\mathrm{b}}>\mathrm{BD} \\
(0.0315<0.097)\end{array}$ & 1.43055 \\
\hline 1 & $\begin{array}{l}\mathrm{A}>>\mathrm{C}>>\mathrm{B}>\mathrm{D} \\
(0.1019<0.1281<0.1655<0.7716)\end{array}$ & $\begin{array}{l}\mathrm{BCD}>\mathrm{AD} \\
(0.0859<0.0970)\end{array}$ & 4.5472 \\
\hline 2 & $\begin{array}{l}\mathrm{A}^{\mathrm{b}}>>\mathrm{C}^{\mathrm{b}}>>\mathrm{D}>\mathrm{B} \\
(0.0005<0.0041<0.1099<0.1880)\end{array}$ & $\begin{array}{l}\mathrm{BD}^{\mathrm{b}}>\mathrm{AD}^{\mathrm{b}}>\mathrm{CD}^{\mathrm{b}} \\
(0.0068<0.0130<0.0467)\end{array}$ & 0.3314 \\
\hline 3 & $\begin{array}{l}\mathrm{C}>>\mathrm{A}>>\mathrm{B}>\mathrm{D} \\
(0.0965<0.1130<0.3210<0.4635)\end{array}$ & & 3.0086 \\
\hline 6 & $\begin{array}{l}\mathrm{A}>>\mathrm{D}>>\mathrm{C}>\mathrm{B} \\
(0.0606<0.0608<0.0851<0.3331)\end{array}$ & $\begin{array}{l}\mathrm{AD} \sim \mathrm{BD}>\mathrm{CD} \\
(0.0632<0.0631<0.0832)\end{array}$ & 0.1406 \\
\hline 12 & $\begin{array}{l}\mathrm{A}>>\mathrm{C}>>\mathrm{D}>\mathrm{B} \\
(0.06571<0.1173<0.1335<0.3824)\end{array}$ & & 3.3491 \\
\hline
\end{tabular}

b: statistically significant; $\mathbf{S}^{2} \mathbf{R}$ : variance of residuals, an estimate of the variation due to experimental error. 
a)

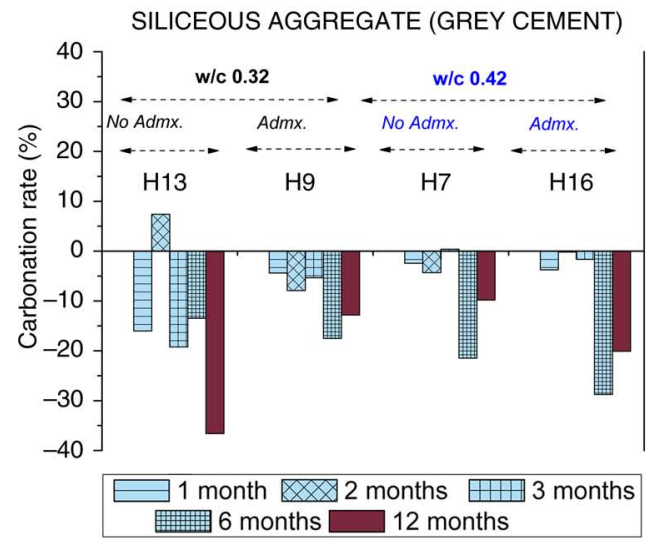

c)

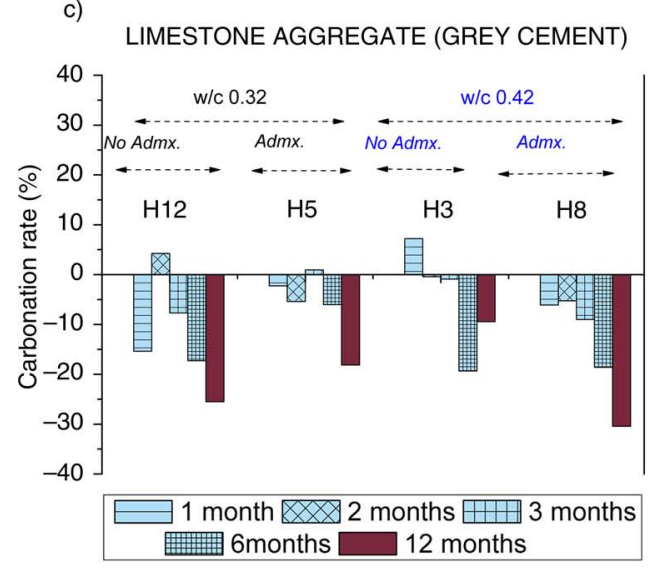

b)

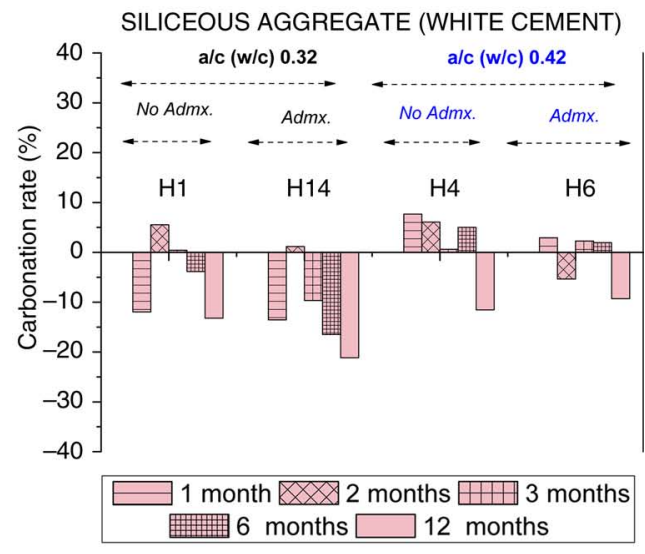

d)

LIMESTONE AGGREGATE (WHITE CEMENT)

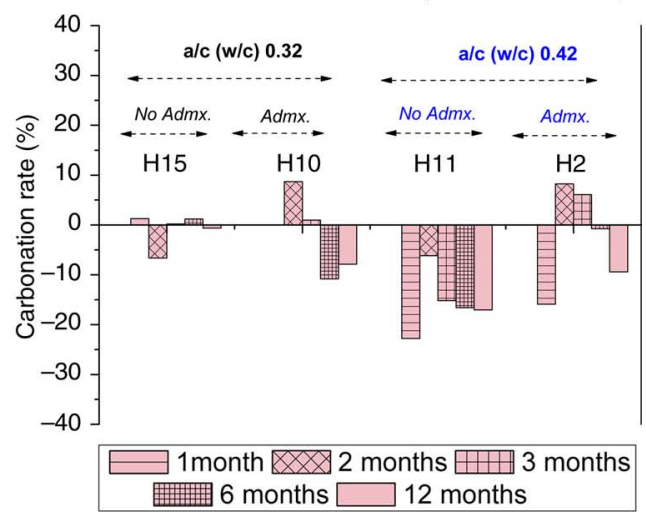

FIGURE 4. Carbonation in all the concretes prepared based on the post-accelerated carbonation variations in their PAW values (2).

signified lower porosity and positive values higher porosity than in the 28-day concrete. Two possible explanations might be given for the occasional increases in the porosity values observed in Figure 3: i) the availability of greater amounts of water; or ii) leaching of the soluble salts present in the matrix (26). Due to the variability of the systems studied, however, no single conclusion could be drawn in this regard.

Certain prior considerations can be gleaned from an analysis of Figure 4. The type of cement appeared to play a significant role in system carbonation, for the concretes made with white cement exhibited smaller reductions in porosity than the analogous grey cement concretes. The presence or absence of an admixture also appeared to be important, for as a rule the concretes with no admixture, particularly the materials prepared with smaller w/c ratios, showed higher carbonation rates (measured as greater declines in their PAW).

While the w/c ratio appeared to be fairly important in white cement concretes, it was less so in the grey cement specimens (again suggesting some type of interaction between cement type and w/c ratio).

\subsubsection{Inferential analysis of variations in carbonation}

The effect of the various factors and their interactions on variations in carbonation are discussed below. The following incremental carbonation variables were designed to represent the difference in concrete carbonation at the ages of 2, 3, 6 and 12 months with respect to the 1-month value: I_1_2, I_1_3, I_1_6 and I_1_12, respectively.

The $\mathrm{p}$-values for each increment are given in Table 4, along with the p-values for the binary and tertiary interactions whose p-values were under 0.1 . Here also, the superscripted "b" and boldface type denote $95 \%$ confidence, and the factors are ranked by decreasing significance.

According to these findings, the only factor that appeared to be statistically significant for the 6- and 12-month variations in carbonation with respect to the 1-month value was the type of cement (factor D) These findings are consistent with the data shown in Figure 4.

The only interaction that proved to be significant for the variation between 1- and 6-month 
TABLE 4. Ranking of factors studied and their interactions by order of significance for variations in the carbonation rate

\begin{tabular}{llc}
\hline $\begin{array}{l}\text { Incremental } \\
\text { variable }\end{array}$ & Factors $^{\mathrm{a}}$ by order of significance & $\begin{array}{c}\text { Binary and } \\
\text { tertiary } \\
\text { interactions }\end{array}$ \\
\hline I_1_2 & $\begin{array}{l}\mathrm{B}>\mathrm{A}>\mathrm{D}>\mathrm{C} \\
(0.5304<0.5644<0.6614<0.9142)\end{array}$ & \\
I_1_3 & $\begin{array}{l}\mathrm{D}>\mathrm{C}>\mathrm{A}>\mathrm{B} \\
(0.3907<0.6505<0.7694<0.9845)\end{array}$ & \\
I_1_6 & $\begin{array}{l}\mathrm{D}^{\mathrm{b}}>\mathrm{B}>\mathrm{A}>\mathrm{C} \\
(0.0123<0.2225<0.4088<0.6769)\end{array}$ & $\begin{array}{c}(0.0192) \\
\text { I_1_12 }\end{array}$ \\
& $\begin{array}{l}\mathrm{D}^{\mathrm{b}}>\mathrm{C}>\mathrm{A}>\mathrm{B} \\
(0.0416<0.5467<0.6517<0.8580)\end{array}$ & \\
\hline
\end{tabular}

carbonation was between cement and the water/ cement ratio. Generally speaking, the residuals revealed no anomalous experimental error patterns.

\section{DISCUSSION}

The statistical analysis of the effect of the various factors studied, i.e., type of cement, type of aggregate, w/c ratio and presence or absence of an admixture, on carbonation, is a very useful tool for establishing priorities. The effect of the factors studied on concrete porosity and variations in its carbonation rate are analysed below.

\section{- Porosity accessible to water}

Statistical analysis revealed that the admixture and type of aggregate (especially the former) are the factors that affect the initial (28-day) porosity of the material most intensely. These findings are consistent with the many studies conducted on the effect of admixtures on concrete pore structure (12-14).

Today, admixtures are essential components in concrete (12-14, 27-30), and superplasticisers are the type most commonly used (accounting for $70 \%$ of the total) (30). The inclusion of small amounts of admixture (less than $1 \mathrm{wt}^{\mathrm{O}} \%$ ) substantially improves both the workability of fresh concrete and the properties of the hardened material. Their use lowers the amount of mixing water needed, which in turn reduces pore size and hence system porosity (see Figure 3 ). That the admixture variable (A) proved to be statistically significant is therefore unsurprising. Moreover, these findings concurred with the several other authors' reports $(6,31)$, whereby the addition of superplasticisers in mortars and concretes lowers porosity and consequently raises mechanical strength.

The other factor that was statistically significant in its own right was the aggregate. Aggregate is the majority concrete component in terms of both volume and mass and is regarded, a priori, as an inert filler for the intents and purposes of carbonation. Nonetheless, as the aggregate is known to affect permeability and porosity, all concrete carbonation models take total concrete mass as their reference $(2,32)$. If aggregate is regarded, a priori, to be chemically inactive, the sole significant change it can only induce changes in concrete porosity and permeability via physical processes (6). Limestone aggregate is known to induce higher capillary water absorption and greater drying shrinkage in concrete than siliceous aggregate (33). That would largely explain the higher porosity accessible to water values in the concretes prepared with this type of aggregate (see Figure 3 ) and the statistical significance of this factor both individually and in its interaction with other explanatory variables.

Taken individually, neither the w/c ratio nor the type of cement appeared to have any direct effect on concrete porosity. Nonetheless, the latter proved to be of vital importance at all ages of the study in its interaction with the admixture, the aggregate and the w/c ratio (interactions $\mathrm{AD}, \mathrm{BD}$ and $\mathrm{CD}$ ). Interaction $\mathrm{AD}$ (admixture-cement) consistently appeared wherever binary interactions were significant. The mechanism governing admixture action in concrete depends on the type of cement used. As Figure 3 shows, the presence or absence of an admixture was particularly important in white cement. The explanation lies in the fact that the fluidising molecules in the admixture are adsorbed intensely onto $\mathrm{C}_{3} \mathrm{~A}(27,28)$, which normally accounts for a higher share of white than grey cement. The greater contact between the anhydrous cement particles and the water induced in white cement favours speedier hydration and precipitation of reaction products, and consequently lower porosities.

\section{- Variations in carbonation}

The most statistically significant factor in the analysis of variations in the carbonation rate was cement, both individually and in its interaction with the w/c ratio (see Table 4 ).

Concrete carbonation takes place in the cement paste, for portlandite $\left(\mathrm{Ca}(\mathrm{OH})_{2}\right)$ and $\mathrm{C}-\mathrm{S}-\mathrm{H}$ gel, which account respectively for 25 and $60 \mathrm{wt} \%$ of the paste content, are the products most liable to be carbonated (2). Obviously, then, the type of cement used may be closely related to carbonation, for this response variable would depend directly on the formation of the aforementioned hydration products. An overview of Figure 4 clearly shows that the type of cement used consistently affected the carbonation rate. This fact was corroborated by the existence of significant interactions between cement and the other explanatory variables, including the w/c ratio.

Surprisingly, the w/c ratio was not statistically significant in its own right with respect to either porosity or carbonation. Water, which is always present to a greater or lesser extent in hardened cement paste pores, is known to play an essential albeit contradictory role in carbonation. It blocks 
pores and consequently hinders $\mathrm{CO}_{2}$ diffusion in concrete, rendering the smallest and generally moisture-saturated capillary pores inaccessible to carbonation, while at the same time favouring the process by providing a medium in which $\mathrm{CO}_{2}$ can react with the C-S-H gel and portlandite $(10,34)$. The net result is that the carbonation front deepens with rising relative humidity and water content in the pore solution. The lack of statistical significance of this variable by itself may be attributed to the fact that the two w/c ratios used were not sufficiently different to observe any material variations in the carbonation measurements: i.e., the values used delivered similar workability and induced no differences in concrete consolidation or the amount of water present in the pore solutions. The statistical significance of the interaction between the w/c ratio and cement over time is logical, however. As the system evolves, its degree of hydration rises, reducing the amount of water available in the pore solution (which initially depends on the w/c ratio). That has a direct effect on the carbonation rate in the concrete.

The present findings showed that while the presence of an admixture and the type of aggregate affected initial system porosity, the type of cement, both individually and in its interaction with the other factors, had the greatest impact on the two response variables studied. Therefore, while initial porosity conditions the carbonation rate, the initially most porous concretes need not necessarily be the ones most intensely carbonated, for that process depends largely on the type of cement and its interactions with other factors.

\section{CONCLUSIONS}

- The factors that proved to be most statistically significant in initial concrete porosity were the presence or absence of an admixture and the type of aggregate.

- Cement and its interactions with the other factors studied appeared to be statistically significant in the analysis of system porosity and the carbonation rate.

- Initial porosity was not the only determinant in carbonation rate, for the concretes that were initially most porous were not necessarily the ones most intensely carbonated.

\section{ACKNOWLEDGEMENTS}

The authors wish to thank Alfredo Gil Maroto and José Luis García for their assistance in experiments conducted and INDAGSA for preparing and supplying the concrete specimens used. Inés GarcíaLodeiro participated in this research project under a Post-Graduate Studies Council grant funded by the Spanish Ministry of Science and Innovation, through the Spanish National Research Council (CSIC).

\section{REFERENCES}

1. Pade, C.; Guimaraes, M. (2007) The $\mathrm{CO}_{2}$ uptake of concrete in a 100 year perspective. Cem. Concr. Res. 371348 1356. http://dx.doi.org/10.1016/j.cemconres.2007.06.009.

2. Papadakis, V.G.; Vayenas, C.G.; Fardis, M.N. (1991) Fundamental modeling and experimental investigation of concrete carbonation. ACI Mat. Jour. 88, 363-373.

3. Saetta, A.; Schrefler, B.A.; Vitaliani, R. (1993) The carbonation of concrete and the mechanism of moisture, heat and carbon dioxide flow through porous materials. Cem. Concr. Res. 23, 761-772. http://dx.doi. org/10.1016/0008-8846(93)90030-D.

4. Glasser, F.P.; Marchand, J.; Samson, E. (2008) Durability of concrete - Degradation phenomena involving detrimental chemical reactions. Cem. Concr. Res. 38, 226-246. http://dx.doi.org/10.1016/j.cemconres.2007.09.015.

5. Glasser, F.P.; Matschei, T. (2007) Interaction between Portland Cement and Carbon Dioxide, XII International Congress of Chemistry Cement 8-13 July Montreal (Canada).

6. Papadakis, V.G.; Vayenas, C.G.; Fardis, M.N. (1991) Experimental Investigations and Mathematical Modeling of theconcretecarbonation problem. Chem. Engen. Sci.46,13331338. http://dx.doi.org/10.1016/0009-2509(91)85060-B

7. Steffens, A.; Dinkler, D.; Ahrens, H. (2002) Modeling carbonation for corrosion risk prediction of concrete structures. Cem. Concr. Res. 32, 935-941. http://dx.doi. org/10.1016/S0008-8846(02)00728-7.

8. Ha-Won Song; Seung-Jun Kwon; Keun-Joo Byun; ChanKyu Park. (2006) Predicting carbonation in early-aged cracked concrete. Cem. Concr. Res. 36, 979-989. http:// dx.doi.org/10.1016/j.cemconres.2005.12.019.

9. Carvajal, A.M.; Silva, C.; Valinete, J.; Venegas, A. (2007) Efectos de la carbonatacion acelerada en distintos tipos de Cementos y Hormigones. Revista de la Construcción 6 [1], 88-97.

10. Chang Cheng-Feng; Chen Jing-Wen. (2006) The experimental investigation of concrete carbonation depth. Cem. Concr. Res. 36 [9], 1760-1766. http://dx.doi.org/10.1016/j. cemconres.2004.07.025.

11. Thiery, M.; Villain, G.M.; Dangla, P.; Platret, G. (2007) Investigation of the carbonation front shape on cementitious material: Effects on the chemical kinetics. Cem. Concr. Res. 37, 1047-1058. http://dx.doi.org/10.1016/j. cemconres.2007.04.002.

12. Izaguirre, A.; Lanas, J.; Álvarez, J.I. (2009) Effect of waterrepellent admixtures on the behaviour of aerial lime-based mortars. Cem. Concr. Res. 39, 1095-1104. http://dx.doi. org/10.1016/j.cemconres.2009.07.026.

13. Cultrone, G.; Sebastian, E.; Ortega Huertas, M. (2005) Forced and natural carbonation of lime-based mortars with and without additives: Mineralogical and textural changes. Cem. Concr. Res. 35, 2278-2289. http://dx.doi. org/10.1016/j.cemconres.2004.12.012.

14. Valcuende, M.; Marco, E.; Parra, C.; Serna, P. (2012) Influence of limestone filler and viscosity-modifying admixture on the shrinkage of self-compacting concrete. Cem. Concr. Res. 42, 583-592. http://dx.doi.org/10.1016/j. cemconres.2012.01.001.

15. Tsivilis, S.; Batis, G.; Chaniotakis, E.; Grigoriadis Gr. Theodossis D. (2000) Properties and behavior of limestone cement concrete and mortar. Cem. Concr. Res. 30,1679-1683. http://dx.doi.org/10.1016/S0008-8846(00)00372-0.

16. Arandigoyen, M.; Álvarez, J.I. (2003) Pore structure and carbonation in blended lime-cement pastes. Mater. Construcc. 56 [282], 17-30.

17. Américo, P.O.; Nepomuceno, A.A. (2003) Cement content influence in rebar corrosion in carbonated mortars Mater. Construcc. 53 [271-272], 113-123. http://dx.doi. org/10.3989/mc.2003.v53.i271-272.296.

18. Aguirre, A.M.; Mejía de Gutiérrez, R. (2013) Durability of reinforced concrete exposed to aggressive conditions Mater. Construcc. 63 [309], 7-38. http://dx.doi.org/10.3989/ mc.2013.00313.

19. Box, G.E.P.; Hunter, J.S. (1978) Statistics for Experimenters, Ed. Wiley, New York. 
20. John, P.W.M. (1971) Statistical Design and Analysis of Experiments, Ed. MacMillan, New York.

21. Peña Sanchez, D. (1989) Estadística. Modelos y Métodos. Alianza Editorial S.A., Madrid.

22. RILEM COMMISSION 25 PEM. (1980) Test N $\mathrm{N}^{\mathrm{a}}$ I.1 Porosity accessible to water, Matériaux et Construction, RILEM, 13 [75], 177-179.

23. Mejía de Gutiérrez, R.; Rodríguez, C.; Rodríguez, E.; Torres, J.; Delvasto, S. (2009) Metakaolin concrete: Carbonation and chloride Behavior. Rev. Fac. Ing. Univ. Antioquia 48, $55-64$.

24. Fernández-Carrasco, L.; Puertas, F.; Blanco-Varela, M.T.; Vázquez, T. (2001) Carbonation of calcium aluminate cement pastes. Mater. Construcc. 51 [263-264], 127-136. http://dx.doi.org/10.3989/mc.2001.v51.i263-264.358.

25. UNE 112 011-94: Corrosión en armaduras: determinación de la profundidad de carbonatación en hormigones endurecidos y puestos en servicio.

26. Hewlettt, P.C. (2006) Lea's Chemistry of Cement and Concrete, Edited by P.C. Hewlett, Elsevier, Butterworth Heinemann, $4^{\text {th }}$ Edition, Oxford UK.

27. Yoshioka, K.; Tazawa, E.; Kawai, K.; Enohata, T. (2002) Adsorption characteristics of superplasticizers on cement component minerals. Cem. Concr. Res. 32, 1507-1513. http:// dx.doi.org/10.1016/S0008-8846(02)00782-2.

28. Ghorab, H.Y.; Kenawi, I.M.; Abdel All Z.G. (2012) Interaction between cements with different composition and superplasticizers. Mater. Construcc. 62 [307], 359380. http://dx.doi.org/10.3989/mc.2012.63610.

29. Seabra, M.P.; Paiva, H.; Labrincha, J.A.; Ferreira, V.M. (2009) Admixtures effect on fresh state properties of aerial lime based mortars. Constr. Build. Mater. 23, 1147-1153. http://dx.doi.org/10.1016/j.conbuildmat.2008.06.008.

30. Alonso, M.M.; Puertas, F.; Palacios, M. (2009) Aditivos para el hormigón: compatibilidad cemento-aditivos basados en policarboxilatos. Monografia del IETcc, 415, IETCC (CSIC), Madrid, Spain.

31. Fortes-Revilla, C.; Martinez-Ramirez, S.; Blanco-Varela, M.T. (2006) Modelling of slaked lime-metakaolin mortar engineering characteristics in terms of process variables. Cem. Concr. Compos. 28, 458-467. http://dx.doi. org/10.1016/j.cemconcomp.2005.12.006.

32. Papadakis, V.G.; Vayenas, C.G.; Fardis, M.N. (1991) Physical and Chemicals characteristics affecting the durability of concrete. ACI Mater J. 8 [2], 186-96.

33. Mosquera, M.J.; Silva, B.; Prieto, B.; Ruiz-Herrera, E. (2006) Addition of cement to lime-based mortars: effect on pore structure and vapor transport. Cem. Concr. Res. 36 [9], 16351642. http://dx.doi.org/10.1016/j.cemconres.2004.10.041.

34. Moreno, E.I.; Domínguez Lara, G.G.; Cob Sarabia E.J.; Duarte Gómez, F. (2004) Efecto de la relación agual cemento en la velocidad de carbonatación del concreto utilizando una cámara de aceleración. Ingeniería 8-2, 117-130. 